\title{
Identification of Helminth Parasites in Dairy Cow through Feces Examination in the Koperasi Unit Desa (KUD) Karangploso Malang
}

\author{
Nurina Titisari, Nurprimadita Rosendiani, Djoko Winarso, Rahadi Swastomo \\ Faculty of Veterinary Medicine, University of Brawijaya. Indonesia

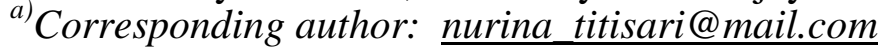

\begin{abstract}
Helminth infections of ruminants are a major constraint on efficient livestock production ${ }^{2}$. Livestock disease caused by parasitic worms may harm the economy, because it can reduce the results of livestock that involves death, weight loss, retarded growth, and low fertility. Indonesia have extensive territory, it is necessary to do research on parasitic worms in various regions in Indonesia. Koperasi Unit Desa (KUD) Karangploso is the second largest milk producer in Malang district after Koperasi Pujon. Examination of feces of dairy cows with diarrhea in KUD Karangploso showed the presence of some Strongyloides sp eggs in the feces examination. It is important to positively detect whether or not the animal against parasitic infestations in order to prevent the spread of parasitic diseases and precise treatment. The purpose of this study to determine the species of helminth in KUD Karangploso region as one of the efforts to eradicate the disease heliminthiasis through examination of feses.The method used is the method of native and floating on 30 faecal samples of dairy cows. The results obtained are showing most of the specimens $(87.5 \%)$ tested positive for helminth eggs. Feces examination was found an infection of Strongyloides sp. (45.8\%), Toxocara sp (25\%), Schistosoma sp (8.3\%), Moniezia expansa (4.2\%), and Trichuris sp.(4.2\%).
\end{abstract}

Keywords: Helminth, KUD, Karangploso, Malang

\section{INTRODUCTION}

The period of lactation in dairy cows is expected to produce as much milk as possible, but if dairy cows are infected it will decrease milk production, lowering the quality of milk and harmful for the calf to drink ${ }^{1}$. Helminth infections of ruminants are a major constraint on efficient livestock production ${ }^{2}$. Livestock disease caused by parasitic worms may harm the economy, because it can reduce the results of livestock that involves death, weight loss, retarded growth, and low fertility. Especially parasitic nematodes are one of the most important causes of production losses in most cattle-producing countries of the world ${ }^{3,4}$. Parasite can cause clinical and non-clinical diseases leading to economic losses that are why veterinarians and producers goal is to prevent the parasitism through management, nutrition, epidemiology, and effective treatment ${ }^{5}$.

Indonesia has extensive territory, it is necessary to do research on parasitic worms in various regions in Indonesia. With the growing number of reports on the prevalence of parasitic worms can reviews these determine the direction of the government policy to be able to speak against this problem. Several studies have been conducted regarding helminthiasis infections in dairy cow. In Indonesia especially in east java several studies indicate there was helminthiasis in dairy cow. Toxocara vitulorum with prevalence is high at $21.33 \%$ in Pasuruan $^{6}$, Fasciola hepatica,

Ascaris sp., Bunostomum sp., Dipylidium caninum, Monieza sp., Haemonchus sp., and 
Trichostrongylus sp in dairy cow in Batu Malang ${ }^{7}$. Research in Batu Malang showed $60 \%$ of helminth infestation in calves of dairy cows ${ }^{7}$. Based on the previous studies indicate many dairy cows suffering from helminthiasis in east java.

Koperasi Unit Desa (KUD) Karangploso is the second largest milk producer in Malang district after Koperasi Pujon. In December 2015, there were some case reported a number of dairy cows with diarrhea in the KUD Karangploso region. Continuous diarrhea in dairy cows can cause a decrease in milk production. Some of the calf aged less than 3 weeks in the area KUD Karangploso also reported suffering of acute diarrhea. Factors that cause diarrhea in cattle or calf is very diverse such as due to disease agents (bacteria, viruses, and protozoa), and non-infectious (environmental and food). After examination of feces of dairy cows with diarrhea showed the presence of some Strongyloides $s p$ eggs in the feces examination.

Diagnosis helminthiasis disease or parasite infestation can be done by seeing clinical signs appear in animals such as diarrhea, dull hair and standing up hair, as well as decreased appetite (anorexia) ${ }^{8}$. These symptoms do not warrant the diagnosis of helminthiasis done precisely and accurately; because most of the animals were exposed to parasitic diseases do not show clinical symptoms (subclinical). Therefore, it is necessary to take measures which can indicate the presence of parasitic infestations in animals, especially for animals that look healthy and show no clinical symptoms. It is important to positively detect whether or not the animal against parasitic infestations in order to prevent the spread of parasitic diseases and precise treatment.

Based on that problem the purpose of this study to determine the species of helminth in KUD Karangploso region as one of the efforts to eradicate the disease heliminthiasis through examination of feses so that the future local government can commit an act of prevention and treatment of helminthiasis in KUD Karangploso Malang region.

\section{MATERIAL AND METHOD}

Samples are taken from several farms in the area KUD Karangploso Malang. Tools and materials used are mortar and pastle, pipette, glass object, cover glass, test tube, tube Erlenmeyer, microscope, sugar or saturated salt solution

Native method is a method of examination of stool directly and without staining. This method quickly and effectively to the examination in severe infections.

Native method ${ }^{9}$ :

1. Weight \pm 3 grams of feces mixed with water as much as $\pm 25 \mathrm{ml}$ until it dissolve

2. take 1- 2 drops of faecal solution using the pipette on object glass

3. cover it with cover glass

4. examined the sample under a microscope with a magnification of $100 \mathrm{x}$ or $400 \mathrm{x}$

Quantitative examination with two flotation is used for this type of parasitic worm eggs which can float by using a saturated sugar or a saturated salt solution. Floating method ${ }^{10}$ :

1. Samples were weighed as much as 3 grams and inserted it in the tube.

2. Then the tube is filled $5 \mathrm{~mL}$ saturated sugar or saturated salt solution, homogenized and refilled it with salt or sugar saturated solution to convex, allowed to stand for 45 minutes.

3. Furthermore, on the mouth of the tube is closed with a glass lid, glass lid removed and placed on a glass object and observed under a microscope

\section{RESULT AND DISSCUSION}

In general, Malang district has a tropical climate with fairly high humidity. The climate is an important factor in the onset of disease cases, where the spread of worm infections occur quite high in the tropics because the humidity level is high enough ${ }^{11}$. The epidemiological 
aspects of parasitic worms, tropical areas with high rainfall led to the accumulation of parasitic worm larvae in the field of animal feed ${ }^{12}$. In addition, from the aspect of ease of the parasite's life cycle, so that the existence of survival of the parasite to the process of contagion or infection of worms to host it easy.

Faecal samples were taken in cattle or calf that showed symptoms of intestinal worms like dull hair, thin bodies, mushy stool etc. The results of feces examination pre-deworming with native methods and floating showing most of the specimens $(87.5 \%)$ tested positive for helminth eggs. The eggs in feces sample is determine as $45.8 \%$

Strongyloides sp (Fig 1), 25\% Toxocara sp, 8.3\% Schistosoma sp, 4.2\% Moniezia sp., and $4.2 \%$ Trichuris $s p$

(Diagram1).

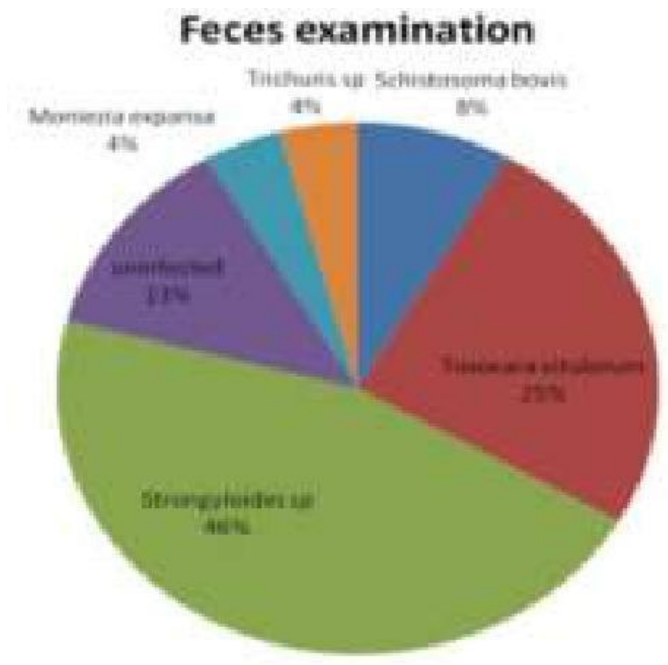

DIAGRAM 1. Result of Feces Examination

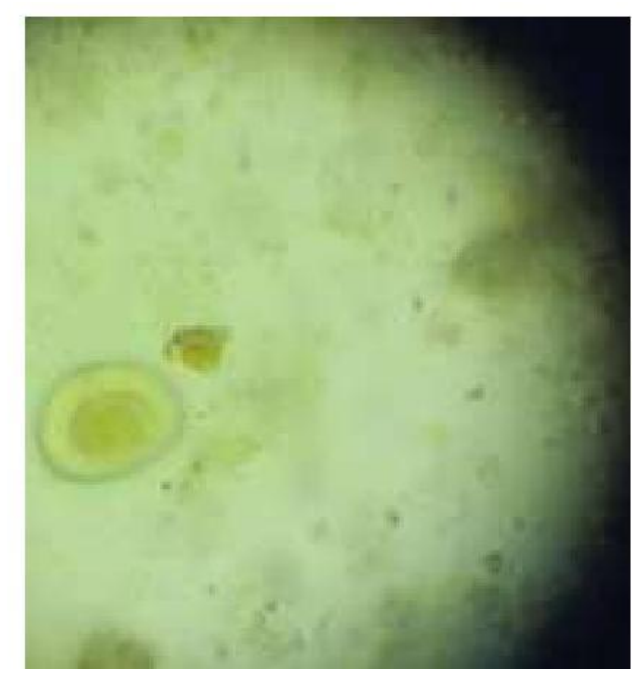

FIGURE 1. Egg of Strongyloides sp.

Percentage types of helminth are quite diverse in the class of nematodes, especially the percentage of infection Strongylus sp. which is quite high, suspected of infection comes from the habit of breeders that are not immediately processed or clean the cow feces, but allowed to accumulate so that if there are worm eggs which issued its host along the feces will quickly multiply into infective eggs and grow in the grass in the surrounding areas or get a natural fertilizer that has many infective worm eggs contaminated. The life cycle of the nematode worm does not require host reservoir, so as to the course of this worm's life cycle easier, while the intestinal parasitic worms from the class of trematodes require host reservoir in order to reach a definitive host ${ }^{13}$.

\section{CONCLUSION}

Type of helmint eggs were found using native and floating methods are Strongyloides sp, Toxocara sp, Schistosoma sp, Moniezia sp., and Trichuris sp. With Strongyloides sp. is the highest frequency which is $45.8 \%$ on dairy cow breeders in the region of KUD Karangploso Malang.

\section{REFERENCES}

1. Hidayati, N. 2014. Prevalensi Telur Cacing Parasit Sapi Perah Friesian Holstein di Unit Pelaksana Teknis Pembibitan Ternak dan Hijauan Makanan Ternak Batu. Skripsi, Jurusan Biologi, Fakultas Matematika dan Ilmu Pengetahuan Alam, Universitas Negeri Malang. Jawa Timur. 
2. Charlier, Johannes, van der Voort, M., Kenyon, F., Skuce, P., \& Vercruysse, J. (2014). Chasing helminths and their economic impact on farmed ruminants. TRENDS IN PARASITOLOGY, 30(7), 361-367.

3. Perry BD, Randolph TF. Improving the assessment of the economic impact of parasitic diseases and of their

control in production animals. Vet Parasitol 1999;84:145e68R. T. Wang, "TitleClassic of $\mathrm{C}$

Physiques, edited by R. B. Hamil (Publisher Name, Publisher City, 1999), pp. 212-213.

4. Sahoo N, Mohanty TN, Samal S. Prevalence of gastrointestinal helminthic infection among grazing and stall-fed cattle in a rainfed district of Orissa. $J$ Vet Parasitol 2002;16:61e2.

5. Kaewthamasorn M, Wongsamee S. A preliminary survey of gastrointestinal and haemoparasites of beef cattle in the tropical livestock farming system in Nan province, northern Thailand. Parasitol Res 2006;99:306e8

6. Susanto, A. 2008. Prevalensi Infeksi Cacing Toxocara Vitulorum Pada Anak Sapi Perah Dan Sapi Potong Di Kabupaten Pasuruan. Undergraduate theses of Airlangga University. Surabaya

7. Iskandar, M. 2015. Efektifitas Albendazole Terhadap Infestasi Cacing Pada Pedet Sapi Perah. Bakau besar pelatihan peternakan (BBPP) Batu. Kota batu.

8. Subronto dan Ida Tjahajati, 2004. Ilmu Penyakit Ternak (Mamalia) II. Gadjah Mada University Press, Yogyakarta.

9. Bistner, I. S., Ford, B.R., and Raffe, M.R. 2000. Handbook of Veterinary Procedures and emergency treatment. United states of america : W.B. Sanders.co

10. Shaikenov, B. T., 2004. Short Report the Use of Polymerase Chain Reaction to Detect Echinococcus granulosus (G1 strain) Eggs in Soil Samples. AM. J. Tropic.sd

11. Williamson, G. and W. J. A. Payne, 1993. Pengantar Peternakan di Daerah Tropis. Universitas Gajah Mada, Yogyakarta.

12. He, Simon, Dwi Sakti Nusantara, Anang Sujana, R. Yati Suwarti. 1991. Gasterointestinal helminthiasis in dairy cows in Bandung and Garut, West Java, Indonesia and its effect on milk production. Journal of Hemera Zoa Vol 74, No 3.

13. Nofyan E, Kamal M., Rosdiana I. 2010. Identitas Telur Cacing Parasit usus pada ternak sapi (Bos sp) dan Kerbau (Bubalus sp) di Rumah Potong Hewan. Palembang. Jurnal penelitian Sains 13:43-46 